remaining material. One intriguing proposal (R. F. Scott, California Institute of Technology) was that a $10-\mathrm{m}$ diameter, $1,000 \mathrm{~g}$ geotechnical centrifuge would permit model experiments on dynamically scaled analogues of natural large landslides.

In spite of the flood of new data on giant landslides, the fundamental cause of their mobility is still far from understood. It is hoped that the new opportunities for the study of their deposits both on other planets and under the sea, and especially of the artificially triggered Soviet geotechnical landslides, will shed new light on this vexing question. It is clear that Western geoscientists have much to gain from cooperation with our Soviet counterparts in the new spirit of glasnost.

H. J. Melosh is in the Lunar and Planetary Laboratory and Department of Geosciences, University of Arizona, Tucson, Arizona 85721, USA.

\title{
Many routes lead to the pole
}

\section{Caroline E. Alfa and Jeremy S. Hyams}

Microtubules in cells do not arise at random. Rather, their organization into arrays such as the mitotic spindle is choreographed by structures known as microtubule organizing centres, which were first recognized over 20 years ago', and which influence the dynamic properties and structural integrity of the polymers assembled onto them. The purification of organizing centres in biochemically useful amounts has proved to be incredibly difficult because they are small and generally there is only one in each cell. But now, writing in the latest issue of Journal of Cell Biology $y^{2}$, Rout and Kilmartin report the isolation and characterization of a particularly well-studied micro-

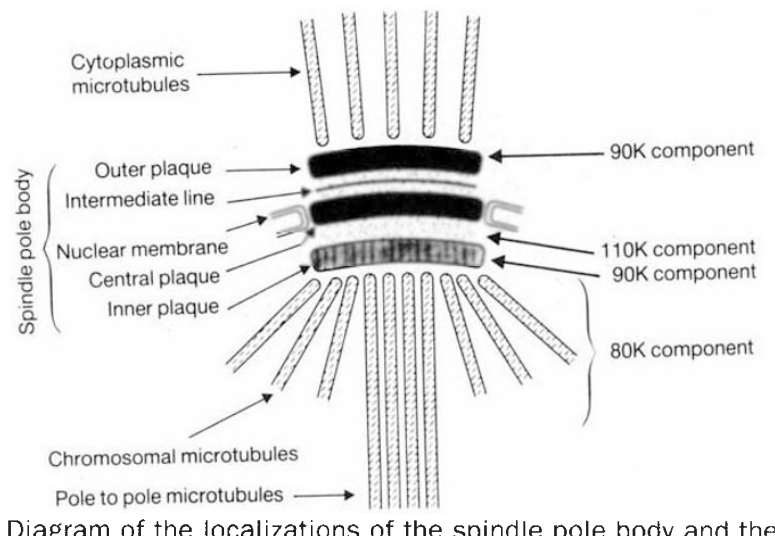
tubule organizing centre. Diagram of the localizations of the spindle pole body and the the spindle pole body of the spindle components (from ref. 2).

budding yeast Saccharomyces cerevisiae.

The spindle pole body of $S$. cerevisiae is a three-layered disk embedded in the nuclear envelope. During interphase, microtubules extend from its outer, cytoplasmic face into the growing bud. As cells enter mitosis, the pole body replicates and about 20 microtubules polymerize onto the inner, intranuclear surface of each daughter, the two sets interdigitating to form the mitotic spindle ${ }^{3.4}$. The yeast spindle pole body is an attractive model for the function of microtubule organizing centres because mutants affecting its structure, replication and copy number have been isolated ${ }^{5-7}$. Moreover, crudely isolated pole bodies retain their capacity to nucleate microtubule assembly in vitro ${ }^{8.4}$. But nothing is known about their biochemistry, nor of the cell-cycle regulation of their microtubule-nucleating functions.

Rout and Kilmartin released spindle pole bodies from highly purified nuclei using a combination of detergent and DNase I in low salt conditions. The resulting preparations, which retain their in vivo morphology and microtubule-nucleating characteristics, were used to raise a battery of monoclonal antibodies which recognized three components of relative molecular mass $110,000,90,000$ and $80,000\left(M_{\mathrm{r}} 110 \mathrm{~K}, 90 \mathrm{~K}\right.$ and $\left.80 \mathrm{~K}\right)$. The association of these proteins with the pole

body, initially confirmed by immunofluorescence light microscopy, was more accurately defined by immunogold electron microscopy. The $110 \mathrm{~K}$ species resides between the pole body's central and innermost layers; because of its distance from the microtubule ends, it is likely to be a structural component rather than being involved in microtubule nucleation. On the other hand, the $90 \mathrm{~K}$ species localizes at the pole body's two faces (from which microtubules grow) and is therefore a potential regulator of microtubule assembly (see figure). The $80 \mathrm{~K}$ protein has a somewhat different distribution, and appears to be associated with the regions of spindle microtubules close to the poles rather than with the pole body itself.

Although these findings do not directly define a role for the proteins concerned, antibodies against them provide a route to the cloning and manipulation of the corresponding genes and a description of their function in vivo is doubtless not too far away. This is particularly timely given a number of other recent insights into the spindle pole body from less direct routes.
One of the most surprising has emerged from the study of genes concerned with another process associated with the pole body, namely, the movement of nuclei towards one another during karyogamy. Onc of these, $K A R 1$, encodes a pole-body component of unknown function " but another, KAR3, has been shown to encode a homologue of the microtubule motor protein kinesin ${ }^{11}$. This colocalizes with the KARl product at the outer surface of the pole body during conjugation but resides at the inner face during mitosis (M. Rose, personal communication).

In the filamentous fungus Aspergillus nidulans and the fission yeast Schizosaccharomyces pombe, genes required for the proper duplication of the pole body at mitosis also encode homologues of kine$\sin ^{12.13}$. Unlike the pole bodies in $S$. cerevisiae, those in $A$. nidulans and $S$. pombe probably act as microtubule organizing centres only in mitosis - the timing of their activation coincides with the phosphorylation of a subset of pole body proteins $^{1+}$ and the appearance at the pole body of the two elements of the mitotic kinase, cdc2 and its regulatory cyclin subunit ${ }^{15}$. How (or even if) these modifications relate to the ability of the pole body to assemble microtubules is not known. But it is tempting to speculate that the link is provided by $\gamma$-tubulin ", which was first found at the pole bodies of $A$. nidulans but which is now thought to be a unique but ubiquitous component of microtubule organizing centres ${ }^{17.1 \%}$. The availability of methods to purify spindle pole bodies and of specific probes to a number of their component proteins will doubtless help investigations into these aspects of pole-body function. Equally clearly, routes to the function of microtubule organizing centres from several directions will continue to converge at the poles.

Caroline E. Alfa and Jeremy S. Hyams are in the Department of Biology, University College London, Gower Street, London WC1E 6BT, UK.

1. Pickett-Heaps, J.D. Cytobios 3, 257-280 (1969)

2. Rout. M.P. \& Kilmartin, J.V. J. Cell Biol. 111, 1913 1927 (1990)

3. Byers, B. \& Goetsch, L. J. Bact. 124, 511-523(1975)

4. Peterson, J.B. \& Ris, H.J. Cell Sci. 22, 219-242 $(1976)$

5. Baum, P.. Furlong, C. \& Byers, B. Proc. natn, Acad. Sci. U.S.A. 83, 5512-5518 (1986)

6. Baum, P., Yip. C., Goetsch. L. \& Byers, B. Molec. cell Biol. 8. $5386-5397$ (1988)

. Uzawa, S. et al Cell62, 913-925(1990)

8. Hyams, J.S. \& Borisy, G.G. J. Cell Biol. 78, 401-414 (1978)

9. Byers, B., Shriver, K. \& Goetsch, L. J. Cell Sci, 30 $331-352(1978)$

10. Rose. M.D. \& Fink, G.R. Cel/ 48, 1047-1060 (1987)

11. Melun, P.B. \& Rose, M.D. Cell 60, 1029-1041 (1990).

12. Enos, A.P. \& Morris, N.R. Cell 60, 1019-1027 (1990)

13. Hagan, I. \& Yanagida, M. Nature 347, 563-566 (1990)

14. Engle, D.B. Doonan, J.H. \& Morris. N.R. Cell Motil Cytoskel 10, 432-437 (1988).

15. Alfa, C.E., Ducommun, B.. Beach. D. \& Hyams, J.S. Nature 347, 680-682 (1990)

16. Oakley, C.E. \& Oakley, B.R. Nature 338, 662-664 (1989)

17. Oakley, B.R., Oakley, C.E., Yoon, Y. \& Jung, M. Cell 61 $1289-1301$ (1990)

18. Tanaka, H. et al. J. Cell Biol. 111, 412a (1990) 